\title{
Criminalization Analysis Of Gambling Crime In The District Court Of The Kudus And Policies That Will Come In Penal Code Reformation
}

\author{
Jajang Supriyatna ${ }^{1}$ and Sri Endah Wahyuningsih ${ }^{2}$
}

\begin{abstract}
The problem in this research are: 1) Criminal prosecution against perpetrators of the Gambling Crime in the Kudus District Court. 2) Analysis of the results verdict against Gambling Crime lawsuit in the District Court of the Kudus. 3) Policy gambling a criminal offense in the Criminal Code reforms to come.
\end{abstract}

Based on the results of the study concluded that: the base of the sentencing process is any act, error, and criminal prosecution. The average charges for the Gambling Crime in the District Court of the Kudus is six (6) months to 1 (one) year, but the result of a prosecution is not equal to the verdict, the general judge handed down the verdict for the Gambling Crime in the District Court of the Kudus average four (4) months to seven (7) months. Viewed from the demands of the course judges are many considerations to decide a case because the trial judges take into consideration the facts and evidence which can relieve the perpetrator gambling. That the main task of a judge is not necessarily just dropped punishment to the offender only. But also think about the consequences of sentencing, as well as considering the impact effect of what will happen later after the imposition of the witness. Creating new regulations on the prohibition of local governments to grant licenses to interested parties regarding the organization of gambling regulations, although in article 303 refer to legalize gambling if there is permission from the competent government in accordance with the PPRI No.9 of 1981. Diction abolish multiple interpretations contained in Article 303 and 303 bus or in the Bill of Article 505 where about peberian permits authorized officials in acts legalize gambling. Make one article where criminal gambling is not only subject to imprisonment and a fine of course, but also deprived of their rights in the professionalism if the perpetrator of a criminal who works with the enhancement.

Keywords: Punishment; Crime Actors; Gambling; Policy; Reform.

\section{Introduction}

In everyday life people often are confronted with an urgent need, the need of gratification. In fact, sometimes the need arises because the desire or pressure to maintain the status themselves. In general, human needs will be met, although not entirely, in a state that does not require pressure from within or from others. To meet the urgent needs, usually often implemented without mature thinking that can harm the environment or other human beings. Things like that will cause a negative effect that is not balanced with the atmosphere and good-value life. ${ }^{3}$

\footnotetext{
${ }^{1}$ Students of Master of Law, UNISSULA, Email: jajangsupriyatna33@gmail.com

${ }^{2}$ Faculty of Law Universitas Islam Sultan Agung

${ }^{3}$ R. Abdoel Djamali, 2014, Pengantar Hukum Indonesia, Rajawali Pers, Jakarta, p.171
} 
From their urgings to maintain the status of human beings sometimes forget how like where to get the property properly. Impacts that will arise from the existence of these influences is a criminal act of gambling where gambling is mostly done in public places is not a secret passage and lago in a community environment. If all members of society to obey the norms and rules, surely society will be peaceful, secure, and peaceful. But in reality, the majority of community members there who do violations of the norms and rules. Violation of the norms and rules that apply in the community known as social deviation.Gambling is often regarded as a disease that is very detrimental society morally and economically. In view of morally because gambling would obviously destroy public morality. In view of the economic terms for the gamble mostly detrimental to people who gamble but benefits the bookies. ${ }^{4}$

Although problem gambling is regulated in laws and regulations, but either in the draft Criminal Law (hereinafter referred to as the Criminal Code) and the Law of the Republic of Indonesia Number 7 of 1974 on Control of Gambling (hereinafter referred to the Law of Gambling Control) appeared to still contain some flaws. This weakness which allows persistence of the gap to the perpetrators of gambling for gambling. As stated in Article 303, paragraph 2, which reads "whoever participated gamble on a public road or alongside a public road or in a place that can be visited by the public, except if there is consent of the competent authority that has been given permission to gambling". From there seen that the Act applied has a weakness to benefit certain groups. So that the Act should be explored in order to provide a deterrent effect against perpetrators of the Gambling Crime not to repeat such actions.

Awareness to the development of national law that is consistent with the level of progress of the nation and in accordance with the way of life and sense of justice, basically has been made since the Declaration of Independence on August 17, 1945, the day followed by the legalization of the Constitution of the Republic of Indonesia in 1945. the provisions of Article II Transitional provisions of the Constitution NRI 1945 still gives place for temporary enactment of legislation emanating from the colonial era, in addition to temporary agency also had to be seen as a mandate to form the new legislation by the Constitution of Indonesia $1945^{5}$.

At the core of law enforcement officials must be more consistent in terms of law enforcement, especially gambling. So that things which are considered as firus gambling or public moral destroyer can be resolved to realize the security and welfare of the community.

Based on the background outlined above, the issues to be discussed in the writing of this study are: 1) How criminal prosecution against perpetrators of the Gambling Crime in the District Court of the Kudus? 2) How to analyze the results of court verdict against

\footnotetext{
${ }^{4}$ Mulyana W Kusuma, 1988, Kejahatan Dan Penyimpangan, YLBHI, Jakarta, p. 55

${ }^{5}$ Sri Endah Wahyuningsih, 2010, Prinsip-Prinsip Individualisasi Pidana Dalam Hukum Pidana Islam Dan Prospek Kontribusinya Bagi Pembaharuan Hukum Pidana Indonesia, Badan Penerbit Universitas Diponegoro, Semarang, p.31-32
} 
the Gambling Crime in the District Court of the Kudus? 3) How to policy gambling a criminal offense in the Criminal Code reform that will come?

The method used in this research that sociological juridical approach, namely a study by conducting studies based on the legislation and the workings of society in the law relating to the Gambling Crime in the Kudus city. This study is included in a descriptive study of exposure. Lengkaptentang aim was to obtain legal circumstances prevailing at a particular place and at the time specific. ${ }^{6}$

\section{Discussion}

\subsection{Punishment Against Perpetrators of Gambling Crime in Kudus District Court}

Gambling games or gambling is the oldest game in the world and almost seriap developed and developing countries recognize as a game of chance. The social impact of gambling or gambling affects the economic circumstances someone besides contrary to morality and decency. Besides gambling also impacts dependence on people who play it, so it can have an impact on the player himself or his family. Conventional losses in 1994 alone reached three (3) billion dollars per year, while gambling with the use of information technology to reach 10 (ten) billion since the beginning of its establishment. ${ }^{7}$

In Indonesia alone gambling games is growing rapidly, although peraaturan legislation say that gambling is a game which is strictly prohibited in Indonesia either conventional gambling and online gambling games. One of the regions in Indonesia with the Gambling Crime that is developing is the Kudus City of Central Java province. Here are a few examples of the Gambling Crime Cases in the Kudus City in the period of 2018 already Incrach.

\subsection{Process Analysis Criminalization against Gambling Crime lawsuit in the District Court of the Kudus}

- Decision No. 119 / Pid.B / 2018 / PN Kds

The judges ruled on imprisonment of the defendants breach of article 303 , paragraph 1 (a) All two of the Penal Code with imprisonment of 4 (four) months for each defendant lighter than the prosecution case that six (6) months imprisonment taking into account the fact the trial and the evidence that there is ease in accordance with the principle theory of joint criminal convictions and the severity of punishment can not exceed a fair retaliation. In this teaching reckoned reprisals, general prevention, as well as the improvement of the criminal purpose, whose function is to Prevent recidivism (to prevent the repetition of criminal acts). ${ }^{8}$

- Decision No. 145 / Pid.B / 2018 / PN Kds

\footnotetext{
${ }^{6}$ Jawade Hafidz, 2009, Metode Penelitian Hukum, Catatan Kuliah, FH UNISSULA Semarang

${ }^{7}$ Sutan Remi Syahdeni, Kejahatan dan Tindak Pidana Komputer, Utama Grafitti, Jakarta, p. 230

${ }^{8}$ Kudus State court, " Decision No. 119 / Pid.B / 2018 / PN Kds / Aug / 2018
} 
The judges ruled on the criminal against the accused on Article 303 , paragraph 1 (a) All two of the Penal Code with imprisonment of 4 (four) months imprisonment for the defendant, lighter than the prosecution case that six (6) months imprisonment taking into account the fact of the trial and evidence alleviate such proof has not been arrested, or convicted before and have family responsibilities. The defendant was found guilty of participating gaming dice unlicensed public authorities. ${ }^{9}$

- Decision No. 152 / Pid.B / 2018 / PN Kds

The judges ruled on the criminal against the accused on Article 303 , paragraph 1 (a) All two of the Penal Code with imprisonment of 4 (four) months and 15 (fifteen) days for the defendant lighter than the prosecution case that six (6) months imprisonment by considering fact of the trial and the evidence that there is ease. The defendant proved to participate in gambling games toggle to earn commissions from unauthorized gambling toggle the competent authorities. However, consideration of the judge for the defendant that the defendant was sentenced to a lighter two months of the prosecution that is 6 months imprisonment by considering first-time defendant committed the Gambling Crime on the grounds fad. The defendant also cooperate in the judicial process and sorry for what has been done and the defendant promised not to repeat his actions again for the purposes of criminal prosecution theory that the principle of joint criminal and penal severity can not exceed a fair retaliation. In this teaching reckoned reprisals, general prevention, as well as the improvement of the criminal purpose, whose function is to Prevent recidivism to prevent the repetition of criminal acts. ${ }^{10}$

- Decision No. 160 / Pid.B / 2018 / PN Kds

Nevertheless, the judges give Hadi Nur alias (Called name) Mbah Nung bin Sholeh defendant violation of article 303, paragraph 1 (a) of the Penal Code with imprisonment of 4 (four) months for the defendant lighter than the prosecution case that six (6) months imprisonment taking into account the fact of the trial and evidence that there is ease in accordance with the principle of the theory of joint criminal convictions and the severity of punishment can not exceed a fair retaliation. In this teaching reckoned reprisals, general prevention, as well as the improvement of the criminal purpose, whose function is to Prevent recidivism (to prevent the repetition of criminal acts.

- Decision No. 167 / Pid.B / 2018 / PN Kds

The judges ruled on offense to three (3) defendant's breach of article 303 paragraph (1) $2^{\text {nd }}$ Book of the Criminal Law in conjunction with the Law of the Republic of Indonesia Number 7 of 1974 About Control Gambling with punishment sentencing four (4) months in prison 3 (three) months lighter than the prosecution case that seven (7) months imprisonment for the trial to consider the facts and evidence have not been convicted ease as before. The defendants also cooperate in

\footnotetext{
${ }^{9}$ Kudus State court, " Decision No. 145 / Pid.B / 2018 / PN Kds / Aug / 2018

${ }^{10}$ Kudus State court, " Decision No. 152 / Pid.B / 2018 / PN Kds / Sept / 2018
} 
the process of judging and promised not to repeat the Gambling Crime again in the future where it is in conformity with the principle of the theory of joint criminal convictions and the severity of punishment can not exceed a fair retaliation. ${ }^{11}$

\subsection{Analysis Of Judges Decision On Gambling Crime In Kudus 2018}

In Indonesia, the agency has the authority to judge and sanction referred to the judiciary. Where the judiciary are state officials who are authorized to hear the case or problems occurring in the society which we know as the Judge. In the statement seen the magnitude of the responsibility of a judge. In deciding whether or not rare to hear a case of a judge to experience what is called inner turmoil in deciding a case where he had to put his ear to the opinion of a sense of justice felt by the community. ${ }^{12}$

One judge at the Court of the Kudus said that the main task of a judge is not necessarily just dropped punishment to the offender only. But also think about the consequences of sentencing, as well as considering the impact effect of what will happen later after the imposition of the witness. Basically, the process is as a stage of criminal sanctions and also the stage of legal sanctions to perpetrators of violations of the act threatened with the intention rules. To judge itself, the basis of the sentencing process is any act, error, and criminal prosecution. The average charges for the Gambling Crime is 6 months to a year. But most convictions against gambling case is 6 months up to 10 months, depending on such factors difficulties and ease.

In the Gambling Crime in the Kudus City itself there are several classifications perpetrators Gambling Crime namely, the bookies are those who open an account at online gambling sites, by opening his own account and offer many of the general public or to invite the general public to participate in gambling with a full commission of the gambling bet money. Method used was already global means online gambling conducted in Kudus no longer controlled by central or provincial bookies but gambling onlin already managed account has been through international networks, such as Singapore and Machao and other major countries. So the difference bookies now and earlier times in Indonesia, particularly the Gambling Crime in the Kudus average are those that are not too stout big capital but control the technology by registering to become a member, open a personal account, after it offered to the public directly.

Heavier where conventional gambling with online gambling, of course heavier online gambling for gambling matters because conventional perpetrator and the victim is himself. As for the nature online gambling, why is said to severe punishment because of whom he is the general public and the people so of course the victim and ruin the effect will be more by way of purchase. So depending on how much effect the loss to the community that will be ballast and weighing the severity of the punishment to be

\footnotetext{
${ }^{11}$ Kudus State court, " Decision No. 167 / Pid.B / 2018 / PN Kds / 17 / Oct / 2018

${ }^{12}$ Satjipto Rahardjo,'"Perang di Balik Toga Hakim"dalam buku: Membedah Hukum Progresif, Jakarta: Kompas, 2006, p.91.
} 
received by criminal gambling. So depending on the legal facts when evidence in the hearing. ${ }^{13}$

\subsection{Policies Gambling A Criminal Offense In The Coming Of Criminal Code Reforms}

If you see or review of Article used in gambling of Article 303 and Article 303, although equally article about gambling but have different criminal threat. Namely Article 303 have criminal penalty 10 years in prison and article 303 have the threat of a maximum of 4 years in prison. Then how is a judge or legal practitioner must wisely apply the appropriate chapter in the use of the article in order to administer justice fairly as possible.

RKUHP in Article 505 that the Parliament and Government of gambling as a moral view with memasaukkan deviate provisions on criminal law to gambling without permission. So it can be said that gambling can be said that gambling could be legalized for permission. The design of the Penal Code Article 505 RKUHP About Gambling.

Still the pros and cons of RUUKUHP Article 505 on the Gambling Crime where in this article could lead to gambling is legal action due to misinterpreting the diction of "unlicensed" which could mean that everyone can gamble origin with permission. Similarly, gambling regulations under Article 303 of the Criminal Code and Article 303 of the Criminal Code that could be gambling may be done by them that are meiliki permit the authorities or the authorities. The existing regulation is less or have weaknesses.

Prevention policies in the future to anticipate the Gambling Crime in Indonesia can be done by means of penal. As some policy formulation that will do improvements are as follows:

- The criminal act of gambling as a form of crime in the area of decency should not only be subject to imprisonment and fined but must also prescribed additional penalty such as the revocation of the right to exercise the profession against the makers of committing criminal offenses gambling in their profession;

- Every form of gambling is not only a criminal act of a private individual who held accountable for the criminal but also the corporate or legal entity can be held to criminal liability.

- In terms of sentencing should be considered a balance between individual interests and the interests of society. Meaning sentence imposed must be adapted and oriented to individual interests. There was also a sense of justice and protection of the public need to be taken into consideration in making a sentencing ${ }^{14}$

\section{Closing}

\footnotetext{
${ }^{13}$ Interview on Judge at the Court of the Kudus State Mr. Edwin Pudyono Marwiyanto, SH, MHtgl / 17 / Dec / 2018 / pkl.09.15

$14 \quad$ https://media.neliti.com/media/publications/3361-ID-kebijakan-hukum-pidana-dalam-rangkapenanggulangan-perjudian.pdf/16.01.2019/at .19 .10
} 


\subsection{Conclusion}

- The basis of the sentencing process is any act, error, and criminal prosecution. The average charges for the Gambling Crime in the District Court of the Kudus is six (6) months to 1 (one) year, but the result of a prosecution is not equal to the verdict, the general judge handed down the verdict for the Gambling Crime in the District Court of the Kudus average four (4) months to seven (7) months. Viewed from the demands of the course judges are many considerations to decide a case because the trial judges take into consideration the facts and evidence which can relieve the perpetrator gambling.

- One judge at the Court of the Kudus said that the main task of a judge is not necessarily just dropped punishment to the offender only. But also think about the consequences of sentencing, as well as considering the impact effect of what will happen later after the imposition of the witness.

- Creating new regulations on the prohibition of local governments to grant licenses to interested parties regarding the organization of gambling regulations, although in article 303 refer to legalize gambling if there is permission from the competent government in accordance with the PPRI No. 9 of 1981. Diction abolish multiple interpretations contained in Article 303 and 303 bus or in the Bill of Article 505 where about peberian permits authorized officials in acts legalize gambling. Make one article where criminal gambling is not only subject to imprisonment and a fine of course, but also deprived of their rights in the professionalism if the perpetrator of a criminal who works with the enhancement.

\subsection{Suggestion}

1. The judge in imposing punishment on criminal acts gambling should be professional in accordance with the results of verification with emphasis on legal facts, contained in the court so that the judge's decision will reflect their sense of justice.

2. Given gambling has become an acute illness in the community, especially in the districts of the Kudus, the need for efforts seriously and systematically, not only from the public and law enforcement officers alone but also are necessary in dealing with such cases will have to reassess the Criminal Code Article 303 and draft Article 505 that, where Article has drawbacks such as giving consent to a particular party. In view of this does not reflect the eradication of gambling, so the government and law enforcement to strictly impose sanctions and deterrent effect against perpetrators of criminal acts in accordance gambling the purpose of criminal law is to give deterrent effect on criminal gambling and to maintain order in society. 


\section{Bibliography}

[1] Jawade Hafidz, 2009, Metode Penelitian Hukum,Catatan Kuliah, FH UNISSULA Semarang

[2] Mulyana W Kusuma, 1988, Kejahatan Dan Penyimpangan, YLBHI, Jakarta.

[3] R. Abdoel Djamali, 2014, Pengantar Hukum Indonesia, Rajawali Pers, Jakarta.

[4] Satjipto Rahardjo, "Perang di Balik Toga Hakim" dalam buku : Membedah Hukum Progresif , Jakarta: Kompas,2006.

[5] Sri Endah Wahyuningsih, 2010, Prinsip-Prinsip Individualisasi Pidana Dalam Hukum Pidana Islam Dan Prospek Kontribusinya Bagi Pembaharuan Hukum Pidana Indonesia, Badan Penerbit Universitas Diponegoro, Semarang.

[6] Sutan Remi Syahdeni, Kejahatan dan Tindak Pidana Komputer, Utama Grafitti, Jakarta, 2009.

[7] https://media.neliti.com/media/publications/3361-ID-kebijakan-hukum-pidanadalam-rangka-penanggulangan-perjudian.pdf/16.01.2019/at.19.10

[8] Interview the Judge at the Court of the Kudus Mr. Edwin Pudyono Marwiyanto, $\mathrm{SH}, \mathrm{MHtgl} / 17$ / Dec. / 2018 / at 09.15 